\title{
42. HOLOCENE CHRONOLOGY FOR THE UNCONSOLIDATED SEDIMENTS AT HOLE 740A: PRYDZ BAY, EAST ANTARCTICA ${ }^{1}$
}

\author{
E. W. Domack, ${ }^{2}$ A.J.T. Jull, ${ }^{3}$ and D. J. Donahue ${ }^{3}$
}

\begin{abstract}
Unconsolidated sediments recovered at Site 740 include approximately $23 \mathrm{~m}$ of interbedded siliceous ooze and silty clay (pebbly mud), which was tentatively assigned a late Pliocene to Quaternary age by shipboard scientists. In order to clarify the chronology of this sequence, six samples of siliceous ooze were analyzed for their ${ }^{14} \mathrm{C}$ content using the University of Arizona Tandem Accelerator Mass-Spectrometer (TAMS) facility. Uncorrected ages ranged from $1915 \pm 50$ yr B.P. $(0.21 \mathrm{mbsf})$ to $11,140 \pm 75 \mathrm{yr}$ B.P. $(15.80 \mathrm{mbsf})$. These ages provide estimates for interval sedimentation rates of the siliceous ooze, which varied from 0.150 to $0.067 \mathrm{~cm} / \mathrm{yr}$. A reservoir correction of $1750 \mathrm{yr}$ is used to determine absolute ages for the sample intervals. These dates ranged from 165 to $9390{ }^{14} \mathrm{C}$ yr B.P. Overall sediment-accumulation rates vary from 0.144 to $0.187 \mathrm{~cm} / \mathrm{yr}$, with maximum rates associated with the pebbly muds rather than the siliceous oozes. Extrapolated sedimentation rates and reservoir corrections allow for an age estimate of about 10,700 yr B.P. for the initiation of open-marine conditions at Site 740. Resumption of terrigenous sedimentation, with increased ice rafting, took place from approximately 7300 to $3800 \mathrm{yr}$ B.P. This may have been related to the readvance of floating ice tongues along the eastern side of Prydz Bay. Open-marine conditions with seasonal sea ice have apparently been in existence near Site 740 for approximately the last $3800 \mathrm{yr}$.
\end{abstract}

\section{PURPOSE}

The purpose of this study was to provide a detailed chronology for the Holocene to late Pleistocene age section that was recovered at Ocean Drilling Program (ODP) Site 740 (Fig. 1; Barron, Larsen, et al., 1989, p. 374). The results have several important implications that are related to both an understanding of regional deglaciation within Prydz Bay and our knowledge of sediment-accumulation rates for biogenic and fine-grained terrigenous sediment in antarctic marine deposystems. Because significant prior work has been completed on terrestrial units in the adjacent Vestfold Hills (Adamson and Pickard, 1986) the information in this study also provides for the first comparison of terrestrial and marine data sets for the Holocene in East Antarctica.

\section{BACKGROUND}

Site 740 in Prydz Bay is located some $30 \mathrm{~km}$ from the coastline within the northeastern part of the Amery Depression (Fig. 1). The Amery Depression is typical of most shelf troughs along the East Antarctic margin in that it lies seaward of major glacier drainage systems and occupies an erosional depression between crystalline basement rock and sedimentary sequences of prerift, synrift, and/or glacial affinities. Though numerous basins of similar character can be found along the East Antarctic margin, the Amery is one of only two that have been investigated with respect to Holocene sediment accumulations; the other is the Mertz-Ninnis Trough, which was discussed by Domack et al. (1989).

Surface sediments within Prydz Bay, including several samples from the Amery Depression, were discussed briefly by Quilty (1985). Two samples of terrigenous mud were collected

\footnotetext{
1 Barron, J., Larsen, B., et al., 1991. Proc. ODP, Sci. Results, 119: College Station, TX (Ocean Drilling Program).

2 Geology Department, Hamilton College, Clinton, NY 13323.

3 NSF-Arizona AMS Facility, University of Arizona, Tucson, AZ 85721.
}

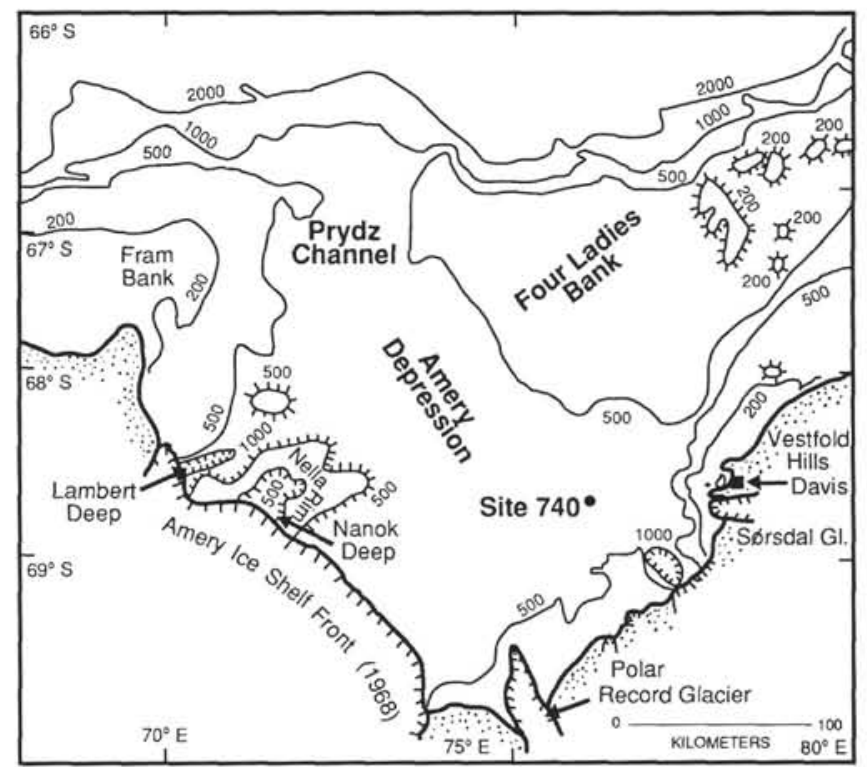

Figure 1. Location, bathymetry, and geographic features of Prydz Bay, East Antarctica. Water depth contours are modified from GEBCO maps and figure 3 in Quilty (1985). Hachured contours indicate bathymetric highs (outside) and depressions (inside).

some $10 \mathrm{~km}$ from the front of the Amery Ice Shelf whereas three samples from the northeast region of the Amery Depression (near Site 740) were found to consist of biosiliceous mud-or ooze (Quilty, 1985).

The sedimentary succession drilled at Site 740 includes approximately $23 \mathrm{~m}$ of interbedded siliceous ooze and silty clay, of which the latter contains a significant component of poorly sorted sand and pebbles and could more accurately be described as a pebbly mud (Fìg. 2; Barron, Larsen, et al., 1989, p. 797- 
780). An interval of poor core recovery between 23 and $56.6 \mathrm{~m}$ below seafloor (mbsf) is thought to consist predominantly of glacial drift and is represented by a drilling breccia of metamorphic clasts in several core-catcher samples. An angular unconformity separates this unconsolidated section from an underlying package of red sandstones, claystones, and conglomerates, which was assigned to a postrift sequence by Barron, Larsen, et al. (1989). The unconsolidated nature of the siliceous ooze and silty clay and the ponded, acoustically transparent character of the accumulation suggested a relatively recent origin for the sediments. A Quaternary age was also suggested by diatom floras examined by shipboard scientists, but the diatoms could have possibly been as old as late Pliocene.

Though core recovery was rather poor, the fact that siliceous oozes were found to be interbedded with terrigenous (glacial marine) sediments indicates that fluctuations in the depositional environment took place during the time of sedimentation at this site. However, the most significant change must have been associated with the recession of grounded ice from the continental shelf to its present position. This event is recorded by the section of bouldery drift (interval below $23 \mathrm{mbsf}$ ) and overlying silty clay (between 16.7 and $23 \mathrm{mbsf}$ ). In order to clarify the timing of this event and subsequent changes in the extent of floating ice, six samples were selected from various levels for ${ }^{14} \mathrm{C}$ dating. Because of the small sample sizes the University of Arizona Tandem Accelerator Mass-Spectrometer (TAMS) facility was used.

\section{ANALYTICAL METHODS}

Six subsamples were processed using standard palynological techniques (Barss and Williams, 1973) in order to determine if any reworked (terrigenous) organic particulates were present in the siliceous ooze. Such allochthonous particulates are known to produce ${ }^{14} \mathrm{C}$ ages that are significantly older than the real age of sediment accumulation (Andrews et al., 1985). Though terrestrial vegetation is lacking, detrital sources of carbon include older bedrock known to contain coal stringers and phytoclasts (Barron, Larsen, et al., 1989). Separate size fractions (greater and less than $38 \mu \mathrm{m}$ ) were examined using a binocular transmitted-light microscope.

Samples for ${ }^{14} \mathrm{C}$ analyses were treated with $3 \mathrm{~N} \mathrm{HCl}$ at $50^{\circ} \mathrm{C}$ to remove calcium carbonate and other acid-soluble material. Samples were filtered in a Buchner funnel using a glass-fiber filter and were combusted at about $900^{\circ} \mathrm{C}$ using $\mathrm{CuO}$ and $\mathrm{MnO}_{2}$. Further details concerning the operation of the Arizona TAMS facility can be found in Linick et al. (1986).

\section{SUMMARY}

The relation of the sediment types encountered in the first three core barrels recovered at Hole $740 \mathrm{~A}$ to the sample locations, recovered intervals, and age vs. sample depths for the sequence are illustrated in Figure 2. The results of the ${ }^{14} \mathrm{C}$ dating and the indicated rates of sedimentation and accumulation for the section are listed in Table 1. Because the ages obtained range from $1915 \pm 50$ to $11,140 \pm 75$ yr B.P., it appears that the entire interval, from 0 to $16.7 \mathrm{mbsf}$, represents sedimentation during the Holocene or latest Pleistocene. Except for the sample at 6.70-6.74 mbsf, the dates show a steady increase in age vs. depth. The apparently anomalous age of $10,770 \pm 70 \mathrm{yr}$ B.P. for Sample AA-3935 is difficult to understand. It is not due to the presence of reworked particulates (see the following), as might be suggested by its close proximity to underlying terrigenous sediments. Description of the cores by shipboard scientists suggested that the interval may be "cave-in" (Barron, Larsen, et al., 1989), but in this case the age should be somewhat younger. It is suggested that the old age for Sample AA-3935 may reflect a significantly greater reservoir effect than the rest of the succession (see the following).

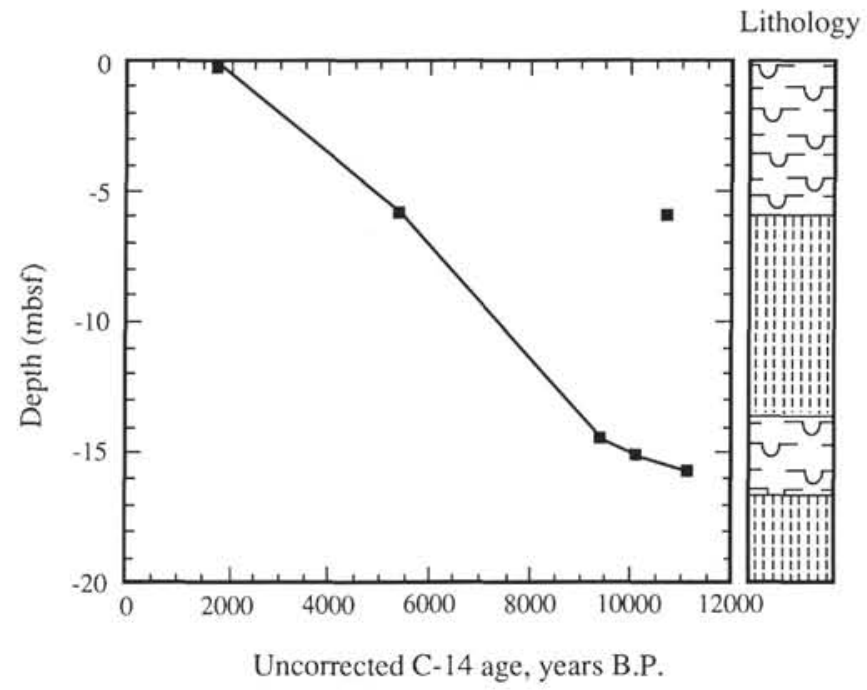

Figure 2. Depth and uncorrected ${ }^{14} \mathrm{C}$ age for Hole 740A samples. The lithology of the succession is taken from Barron, Larsen, et al. (1989). Note the greater rate of sedimentation for the upper silty clay (pebbly mud) interval.

The age data can be interpreted in several ways. The difference in uncorrected ages between samples can be used to establish sedimentation rates between sample intervals (Table 1). By applying a known reservoir-correction factor absolute (corrected) dates for sediment intervals can also be determined. In this way accumulation rates from the surface to the dated interval can be calculated (Table 1). This latter method assumes that the top of the recovered sediment (in the core) corresponds to the actual sediment/water interface and that bioturbation (vertical mixing) is not substantially different between core intervals. This is a correct assumption for Hole $740 \mathrm{~A}$ because living foraminifers were recovered from the top of Section 119-740A-1R-1 (Barron, Larsen, et al., 1989, p. 357). The extrapolation of interval sedimentation rates to the top of the section indicates that the modern sediment would have an apparent ${ }^{14} \mathrm{C}$ age of about $1750 \mathrm{yr}$ B.P. Such an old surface date is believed to be an indication of the depletion of ${ }^{14} \mathrm{C}$ in antarctic surface waters rather than the presence of reworked "detrital" carbon. Thorough examination of the organic particulates from each of the samples revealed a dominance of amorphous marine algal matter that is autochtonous in origin. Only two reworked pollen grains were found in the 12 slides that were examined. These, along with several other "reworked" particles, were present in Sample AA-3938 from Section 119-740A-3R-2.

The depletion of ${ }^{14} \mathrm{C}$ in antarctic surface waters is due to $\mathrm{CO}_{2}$ sources derived from glacial melting (Omoto, 1983) and to the upwelling of "old" deep waters onto the continental shelf (Stuiver and Ostlund, 1983). The reservoir correction of 1750 yr B.P. for eastern Prydz Bay is significantly younger than reservoir ages from the Mertz-Ninnis Trough established by Domack et al. (1989). However, it does compare reasonably to a date of 1300 yr B.P. for modern marine sediments collected adjacent to Davis Station (Fig. 1; Adamson and Pickard, 1986). Hence, in order to establish absolute accumulation rates and ages for sample intervals a reservoir correction of $1750 \mathrm{yr}$ is used.

Sediment-accumulation rates vary from a high of 0.187 $\mathrm{cm} / \mathrm{yr}$ for the section above $14.5 \mathrm{mbsf}$ to a low of $0.144 \mathrm{~cm} / \mathrm{yr}$ for the upper Holocene section of siliceous ooze (Table 1). This is about one-half the rate for siliceous ooze sedimentation in the Mertz-Ninnis Trough (Domack et al., 1989), which suggests a significant difference between the two areas in either long-term 
Table 1. Sample depth, uncorrected ${ }^{14} \mathrm{C}$ age, and derived sedimentation rates between dated samples and accumulation rates from the surface.

\begin{tabular}{|c|c|c|c|c|c|}
\hline $\begin{array}{l}\text { Core, section, } \\
\text { interval }(\mathrm{cm})\end{array}$ & $\begin{array}{l}\text { Depth } \\
\text { (mbsf) }\end{array}$ & $\begin{array}{l}\text { Uncorrected } \\
{ }_{14} \mathrm{C} \text { age } \\
\text { (yr B.P.) }\end{array}$ & $\begin{array}{c}\text { Interval } \\
\text { sedimentation } \\
\text { rate }(\mathrm{cm} / \mathrm{yr})\end{array}$ & $\begin{array}{c}\text { Accumulation } \\
\text { rate } \\
(\mathrm{cm} / \mathrm{yr})\end{array}$ & $\begin{array}{l}\text { Sample } \\
\text { number }\end{array}$ \\
\hline \multicolumn{6}{|l|}{$119-740 \mathrm{~A}-$} \\
\hline $1 R-1,21-26$ & $\begin{array}{l}0.21- \\
0.26\end{array}$ & $1915 \pm 50$ & a_ & 0.144 & AA-3933 \\
\hline IR-2, 3-7 & $\begin{array}{l}\text { b } 5.88- \\
5.92\end{array}$ & $5485 \pm 60$ & 0.15 & 0.158 & AA-3934 \\
\hline $2 \mathrm{R}-2,0-4$ & $\begin{array}{l}6.00- \\
6.04\end{array}$ & $10,770 \pm 70$ & a_ & $a_{-}$ & AA-3935 \\
\hline $3 R-1,80-84$ & $\begin{array}{l}14.50- \\
14.54\end{array}$ & $9480 \pm 65$ & 0.21 & 0.187 & AA-3936 \\
\hline $3 \mathrm{R}-1,146-150$ & $\begin{array}{l}15.16- \\
15.20\end{array}$ & $10,175 \pm 85$ & 0.095 & 0.180 & AA-3937 \\
\hline $3 R-2,60-64$ & $\begin{array}{l}15.80- \\
15.84\end{array}$ & $11,140 \pm 75$ & 0.067 & 0.168 & AA-3938 \\
\hline
\end{tabular}

Note: Recovery: 0-6 mbsf, $16.5 \%$; 6-13.7 mbsf, 9.5\%; 13.7-23.2 mbsf, 53.8\%.

${ }^{a}$ Rates cannot be calculated because of the anomalous age of Sample AA-3935 and lack of data above 0.21 mbsf.

$\mathrm{b}$ Because of incomplete core recovery this sample may be as high as $0.89-0.93 \mathrm{mbsf}$.

primary production or the manner in which biogenic particles are distributed to the seafloor. The average accumulation rate for the entire interval at Site 740 is $0.167 \mathrm{~cm} / \mathrm{yr}$. In contrast, interval sedimentation rates vary from a high of $0.21 \mathrm{~cm} / \mathrm{yr}$ for the silty clay (pebbly mud) to a low of $0.067 \mathrm{~cm} / \mathrm{yr}$ for the lower siliceous ooze (Table 1). Combined, these data indicate that the silty clay interval represents a period of a greater sedimentation rate, in comparison with the siliceous oozes (Fig. 2). This observation has direct bearing on the environmental interpretation of the silty clay (pebbly mud) interval.

Under the present climatic conditions pebbly muds could conceivably be deposited in two different settings. This would include sub-ice shelf or -ice tongue environments and beneath permanent sea ice. The latter setting could produce pebbly, silty clays under reduced accumulation of biogenic particulates and slow rates of hemipelagic sedimentation coupled with periodic iceberg rafting. Because biogenic contributions would be greatly restricted beneath the sea ice, the rate of sediment accumulation in this setting would necessarily have to be less than that of a siliceous ooze. Without fluvial input and a normal littoral zone of shallow water, transport and deposition of terrigenous sediment from sea ice would also be quite low. Instead, pebbly mud units were likely deposited beneath, or close to, floating glacier ice, perhaps in an ice tongue or ice shelf environment. The pebbly muds are, therefore, examples of compound glacial marine sediments as defined by Anderson et al. (1982). Because the clastic sediment supply would be greater under confined ice shelf conditions, both fine-grained clastic material and ice-rafted debris could be deposited at rates greater than siliceous ooze deposition. Surface sediments found in deep water close to the Amery Ice Shelf consist of silty clay (Quilty, 1985). Prior to 1964 these sites were beneath the outer edge of the Amery Ice Shelf, which has since receded to the approximate position shown in Figure 1 (Holdsworth, 1985). These two observations implicate a similar paleoenvironmental setting (sub-ice shelf) for the silty clay units at Site 740 .

Reservoir-corrected ages for the samples suggest that the initial period of open-marine conditions (siliceous ooze deposition) began approximately 10,700 yr B.P. and was succeeded by a readvance of floating glacial ice (ice tongues or ice shelf) at about $7400 \mathrm{yr}$ B.P. Hence, a period of approximately $3300 \mathrm{yr}$ is recorded by the lower siliceous ooze interval at Hole 740A (Fig.
2). The mid-Holocene readvance of glacial ice lasted approximately $4100 \mathrm{yr}$ and was succeeded by renewed open-marine conditions, beginning at about $3800 \mathrm{yr}$ B.P., which have apparently persisted to this time. Without additional sedimentologic detail, such as the provenance of the ice-rafted fraction, it is difficult to assess the exact source of the ice margins involved in this scenario. Also, because of the poor core recovery, it possible that more than one pebbly mud unit may exist within the Holocene sequence at Site 740 .

The initial recession, at about 10,700 yr B.P., was most likely related to retreat from late Wisconsin glacial maximum conditions that may have involved the Amery Ice Shelf/Lambert Glacier system. From studies of the Vestfold Hills (Fig. 1) it is known that coastal outcrops were free of ice by at least $8000 \mathrm{yr}$ B.P. (Adamson and Pickard, 1986). However, areas adjacent to outlet systems, such as the Sørsdal Glacier (Fig. 1), remained ice covered until much later (about 5000 yr B.P.). This suggests that extensive ice tongues could have been present along the northeast edge of Prydz Bay through most of the Holocene. The margin of the Sørsdal Glacier remains floating to this day. Adamson and Pickard (1986) also reported a limited readvance of ice, presumably related to greater ice volume within the Sørsdal Glacier, which they named the Chelnok glaciation. This readvance was tentatively assigned to a period of between 3000 and $1500 \mathrm{yr}$ B.P. and, hence, is significantly more recent than the mid-Holocene event recorded at Site 740 . It is suggested that the readvance at Site 740 occurred during a time when the Sørsdal Glacier remained near its Holocene maximum within the Vestfold Hills, though glacial ice cover at Site 740 may have been related to an expanded Amery Ice Shelf in concert with other outlet systems found along the northeast edge of Prydz Bay (Fig. 1). Because climatic events in Antarctica are poorly constrained during this period it is difficult to establish causative mechanisms for the readvance. Possibilities include neoglacial climate forcing, surging, or dynamic adjustment of the Lambert/Amery grounding line system to decreasing rates of relative sea-level change.

The drilling results at Site 740 and the chronology presented in this manuscript confirm the contention that a detailed and significant Holocene record is present within shelf troughs of the East Antarctic margin (Domack et al., 1989). The existence of interbedded terrigenous and biogenic muds indicates that a 
history of both ice fluctuation and paleoproductivity can be obtained from this climatically sensitive region.

\section{ACKNOWLEDGMENTS}

This project was supported by NSF grants EAR 85-12761 (to A.J.T. Jull) and DPP 86-13565 (to E. W. Domack). We would like to thank the staff at the ODP East Coast Core Repository for their help in obtaining samples.

\section{REFERENCES}

Adamson, D. A., and Pickard, J., 1986. Cainozoic history of the Vestfold Hills. In Pickard, J. (Ed.), Antarctic Oasis Terrestrial Environments of the Vestfold Hills: New York (Academic Press), 63-98.

Anderson, J. B., Kurtz, D. D., Domack, E. W., and Balshaw, K. M., 1980. Glacial and glacial marine sediments of the Antarctic continental shelf. J. Geol., 88:399-414.

Andrews, J. T., Jull, A.J.T., Donahue, D. J., Short, S. K., and Osterman, L. E., 1985. Sedimentation rates in Baffin Island fjord cores from comparative radiocarbon dates. Can. J. Earth Sci., 22:18271834.

Barron, J., Larsen, B., et al., 1989. Proc. ODP, Init. Repts., 119: College Station, TX (Ocean Drilling Program).

Barss, M. S., and Williams, G. L., 1973. Palynology and Nannofossil Processing Techniques. Geol. Surv. Can., Pap. 73-26.
Domack, E. W., Jull, A.J.T., Anderson, J. B., Linick, T. W., and Williams, C. R., 1989. Application of tandem accelerator mass-spectrometer dating to late Pleistocene-Holocene sediments of the East Antarctic continental shelf. Quat. Res., 31:277-287.

Holdsworth, G., 1985. Some effects of ocean currents and wave motion on the dynamics of some floating glacier tongues. In Jacobs, S. (Ed.), Oceanology of the Antarctic Continental Shelf: Am. Geophys. Union, Antarct. Res. Ser., 43:253-271.

Linick, T. W., Jull, A.J.T., Toolien, L. G., and Donahue, D. J., 1986. Operation of the National Science Foundation accelerator facility for radiocarbon isotope analysis and results from selected collaborative research projects. Radiocarbon, 28:522-533.

Omoto, K., 1983. The problem and significance of radiocarbon geochronolgy in Antarctica. In Oliver, R. L., James, P. R., and Jago, J. B. (Eds.), Antarctic Earth Science: Canberra (Australian Acad. Sci.), 450-452.

Quilty, P. G., 1985. Distribution of foraminiferids in sediments of Prydz Bay, Antarctica. Spec. Publ. S. Aust. Dep. Mines Energy, 5:329340.

Stuiver, M., and Ostlund, H. G., 1983. GEOSECS Indian Ocean and Mediterranean radiocarbon. Radiocarbon, 25:1-28.

Date of initial receipt: 16 November 1989

Date of acceptance: 4 June 1990

Ms 119B-207 